\title{
Bozka abertzalea eta independentismoaren arteko harremana Euskal Autonomia erkidegoan
}

\author{
The relationship between abertzale and independentism \\ vote in the Basque Country
}

Eider Alkorta Elorza • eider.alcorta@ehu.eus

UNIVERSIDAD DEL PAÍS VASCO/EUSKAL HERRIKO UNIBERTSITATEA

SOZIOLOGIA II SAILA

Recibido: 04-04-2016

Aceptado: 15-05-2016

\section{Laburpena}

Artikulu honetan Euskal Autonomia Erkidegoan alderdi abertzaleek jasotzen duten bozka eta independentzia nahien arteko harremana dugu aztergai. Horretarako, 1994-2012 bitartean hauteskunde autonomiko ezberdinetan alderdi abertzaleek jasotako bozka eta herritarrek erakutsitako independentzia nahiak alderatu ditugu. Modu honetara, alderdi abertzaleek izan ditzaketen gorabeherak eta mobilizazio iturri nagusiak herritarren independentzia nahien adierazle egokiak diren aztertu nahi dugu. Izan ere, gurean nortasunaren dimentsioak eragin handia du hauteskunde portaeran, baina ez dago hain argi nortasunaren edota nazionalismoaren balio politikoak zuzenean erkatu ditzakegun independentzia edota sezesio nahiekin.

Hitz gakoak: abertzaletasuna, independentzia, bozka, identitatea, hauteskunde portaera

\section{Abstract}

In this paper we analyze the relationship between the votes received by nationalist parties and the desire for independence in the Basque Autonomous Community. To do this, we compare the electoral support of nationalist parties in the elections in the period 1994-2012 and citizens' support for independence as registered in different surveys. Thus, we want to know if the fluctuations in nationalist parties support and in their sources of mobilization are indicators of the desire for independence of citizens. In the Basque case, the dimension of identity has a great influence on voting behavior, but it is not clear whether the political values related to identity or nationalism are comparable with the demands for independence or secession.

Key words: nationalism, independence, secessionism, vote, identity, electoral behaviour 


\section{SARRERA}

Hauteskunde portaeraren azterketaren garai modernoaren hastapena 1944. urtean koka dezakegu. Urte horretan, Paul Lazarsfeld eta Kolunbiako Unibertsitateko Ikerketa Sozial Aplikatuko Bulegoak akademi-izaera zuen hauteskundeen lehen ikerketa burutu zuen, The People's Choice. Kolunbiako soziologoak ordea, ez ziren bakarrak izan hauteskunde ikerketa batean begirada boto-emaileengan zentratu zutenak. Beste bi ikerketa korronte ere garai honetan eratu ziren; Campbell, Converse, Miller eta Stokesen (1960) The American Voter eta Anthony Downsen (1957) An Economic Theory of Democracy. Ohikoa da hiru tradizio hauek era bananduan aztertzea eta ezberdintasunei erreparatzea baina, hein handi batean, tradizio bakoitzak teoria demokratikoaren erronka ezberdinei heldu ziola esan dezakegu (Carmines eta Huckfeldt:2001).

Kolunbia eta Michiganeko ereduek hautesleak politikoki oso sofistikatuak ez direnaren ideia eta gizarte moderno bateko bizitza politikoaren konplexutasunaren inguruko informazio urria dutenaren ideia partekatzen dute. Horregatik, hauteskundeetan erabakiak hartu ahal izateko, aztarna batzuk (cues) behar dituzte. Kolunbiako eskolaren kasuan, aztarna hauek gizabanakoen giza talde edo erreferentziazko taldeen portaera eta balore nagusietatik eratortzen dira. Michiganeko ereduari jarraiki aldiz, aztarna hauek alderdi identifikaziotik sortuko lirateke (Mayer, 2006:20 in Sulmont Haak, 2010:4). Downsen ereduaren aburuz, herritarren arrazionalitate utilitaristak bere alderdi identifikazioak edota talde sozial ezberdinetako kidetzak baino eragin gehiago luke bere hauteskunde orientabideetan. Ildo honi jarraiki, herritarren erabakia hautagaiei buruzko iritzian, iraganean egindako lanaren ebaluazioan edota aurrera eginiko promesetatik izan ditzakeen irabazietan oinarritua dagoela espero da.

Jarraian, korronte bakoitzaren markoetatik haratago, EAEn hauteskunde partehartzea baldintzatu dezaketen faktore ezberdinen zertzelada nagusiak azalduko ditugu. Horretarako, Campbell eta beste ikertzaile batzuk 60.hamarkadan proposaturiko bozka eredua izan dugu oinarrian (Campbell et al.,1960). Bozka eredu hau "kausalitate-inbutu" bezala ezaguna da eta irudiaren muturrean gizabanako eta alderdien arteko harreman egonkorrak sortzen dituzten oinarriak ditugu, egiturazko aldagai sozialak, ekonomikoak eta politikoak. Alegia, gizabanakoen posizio soziala definitzen dutenak. Beste muturrean, hauteskunde batetako ezaugarri konkretuak marrazten dira, besteak beste, ingurumaria ekonomikoa edo politikoa eta hautagaitzen eraketa. Bi muturren arteko lotura, gizabanakoek hautagaiekiko, eztabaida politikoaren gai edo arazoekiko eta alderdi politikoekiko garatzen dituzten jarreren bidez ematen da.

Eredu honi jarraiki, hauteskunde partehartzea aztertzeko orduan honako faktore hauek hartu beharko genituzke kontuan:

- Hauteslearen posizio soziala: generoa, adina, ikasketa maila, diru sarrerak edota bizitokia.

- Hauteslearen jarrera politikoak: interesa, politizazio maila edota sistema eta erakundeen balorazioa. 
- Hauteskundeen testuinguru politikoa: hauteskunde sistema, hauteskunde lehia edota pizgarri instituzionalen sistema.

Hautesleen posizio soziala, klase soziala, erlijio komunitatea, jatorria edo egiturazko beste banaketen araberakoa izan daiteke. Espainiako Estatuaren kasuan, bai Katalunian eta bai EAEn, espainiar immigrazioak jatorri nazional ezberdinak dituzten kolektibitateak egotea ahalbidetu du. Etnikoki ere, Euskal Herriko aurreko lerroketa batek euskaldun eta fededun hitzak kidetu egiten zituen. Denborarekin eta gertatu izan den sekularizazioak lokarri hori zeharo apurtu du. Jatorriaren araberako bozkak bertsio ezberdinak hartzen ditu tokiaren arabera (Harrop eta Miller, 1987:176). Belgika eta estatu gabeko nazioetan, jatorriak nortasun nazional ezberdinetan oinarrituriko banaketa bat islatzen du. Baina nortasun nazionalaren cleavageak zer nolako eragina du hauteskundeetan? Belgiar eredua muturrekoa bada ere, Katalunian eta EAEn ere ardatz honen eragina esanguratsua da. EAEri dagokionean hauteskunde portaeran era zuzenean eragiten duen faktorea da nortasun nazionalarena. Balio aurrepolitikoa izanik ere, nazionalismoan eragina du, eta hortaz, gurean, bozka erabakitzeko funtsezko aldagai eta balio politikoa litzateke.

Balio politikoei helduaz, hauteskunde portaeraren azterketetan, bereziki, ezker-eskuin ideologia, alderdi batekiko identifikazioa eta nazionalismoaren balio politikoei erreparatzen zaie. Balio politikoez hitzegiten dugunean, kultura politikoaz, identifikazio politikoez, jarrera politikoez edota iritzi publikoaz ari gara (Anduiza eta Bosch, 2012:187).

Bozkaren eredu ideologikoari dagokionean, Irlanda da eredu hau gutxien betetzen deneko herrialdea. Bertan, ezkerreko hautesle askok ez diete bozka ezkerreko alderdiei ematen eta, alderantziz, eskuineko hautesle askok ez dituzte eskuineko alderdiak bozkatzen. Honela, hautesle askok bozka ez dute ezker-eskuin ideologiaren arabera aukeratzen, baizik eta nazionalismo graduaren arabera. Europari begira, Irlandaz gain nazionalismoaren balio politikoak eragin handia du Belgika, EAE edota Katalunian. Modu honetara, bozkan gehien eragiten duten balio politikoak aldatuz doaz herrialdeen arabera. Europa kontinentalean ezker-eskuin ideologia da bozkan gehien eragiten duen balio politikoa, baina beste batzuetan nazionalismoa da ardatz nagusia, eta Estatu Batuetan alderdi politiko batetiko identifikazioa izanen da balio nagusia.

EAEri dagokionean bi lerrokatze ezberdin nagusitzen dira, eta gure ustez, lehen lerrokatzea, nagusia, nazionalismoarena litzateke, eta ondoren, ezker/eskuin ideologiarena. Gure aburuz beraz, ezker-eskuin ardatzak baino eragin handiagoa luke nazionalismoak EAEko herritarren hauteskunde portaera baldintzatzeko unean. Halere, nortasun nazionala, eta ondoren nazionalismoaren balio politikoaren indarra eta eragina azpimarratzeak, ez du ukatzen gurean ezker-eskuin ideologiak izan dezakeen eragina. EAEko mapa politikoa, orokortuz bada ere, lau espazio politikoetan banandurik egon dela esan genezake. Mapa horretan, alderdi politikoak abertzale/ez abertzale izaeraz gain, ezker-eskuin ideologiaren arabera ere bananduak daudela ikus dezakegu. Honela, ezkerrean edo eskuinean koka ditzakegun alderdi abertzaleak eta ez abertzaleak ditugu. 
Modu honetara, herritarren bozka erabakitzeko orduan abertzaletasunak lehentasuna izanik ere, ondoren ezker-eskuin ardatzaren araberako bigarren hautu bat eginen dute. Une hauetan halere, EAEn balizko bosgarren espazio baten birsortzea ere irudika genezake, Podemos Gasteizko legebiltzarrean indartsu sartu daitekenaren aurreikuspenak medio, hein batean, abertzale/ez abertzale ardatza gaindituko lukeen esparru batean. EAEko lerrokatze nagusia nazionalismoaren baitakoa dela azaldu dugu, bigarren pausu batean herritarrek ezker/eskuin ardatzaren araberako hautua egingo lukete. Posible da ordea, eta bereziki alderdi abertzaleei begira, hautu horren oinarri nagusia ez izatea ideologikoa, bi espazioen baitako alderdi ezberdinen beste ezaugarri batzuei lehentasuna emanez.

Aukera abertzalea egiten duten herritarrei erreparatuz, enpirikoki ezin dugu jakin jendeak ezkerreko klabeetan kokatzen delako bozkatzen dion Ezker Abertzaleari, edota EAJri eskuinekoa delako. Beste faktore batzuk ere eragin handia dutela uste dugu, ETAren indarkeriaren inguruko jarrera, kultura politikoa edota independentismo maila esaterako. Finean, gurean bi nazionalismo ezberdindu ditugu; nazionalismo instituzionala bezala definitu dezakeguna eta nazionalismo arradikala bezala definitu dezakeguna. Euren praktika eta diskurtso politikoa ezberdinak izan dira eta benetan ezberdintasunen gako nagusia irizpide ideologikoetan baino, beste ardatz batzuetan kokatzen dela esan genezake. Gainera, euskal nazionalismoaren bi arimek balio edota irudi ezberdina islatu izan dute; nazionalismo instituzionala tradizioarekin, agintaritza politikoarekin eta pragmatismoarekin harremantzen da eta, nazionalismo erradikala aldiz, berrikuntzarekin, hausturarekin eta ikuspegi alternatibo batekin. Hortaz, ezker-eskuin ideologiak izan dezakeen eragina bazterrean utzi gabe, aipaturiko aldagaiek ere nazionalismoaren baitako bi hautu nagusien arteko aukeraketan herritarrengan eragin esanguratsua duenaren ustea mantentzen dugu.

Bozkaren kausazio ereduarekin jarraituz, posizio sozialak balio politikoetan bilakatu beharko lirateke bozkan eragin ahal izateko. Baina balio politikoak ere ez dira guztiz determinanteak hauteslearen bozka azaltzeko orduan. Hirugarren elementu bat falta zaigu bozkaren kausazio prozesua osatzeko; hauteskunde ingurumariarena. Autore ezberdinen arabera, 60 eta 70. hamarkadak bozkaren aldakortasunaren erakusle dira eta lerrokatze aldakorrak nabarmenak izan ziren alderdi tradizionalei dagokienean. Ildo honi jarraiki, Kolunbia eta Michiganeko eredu klasikoen baliagarritasun analitikoa auzitan geratu zen; bereziki, sozializazio prozesuarekin, talde edota cleavage sozialen pisuarekin edota alderdi eta ideologia identifikazioarekin harremanduriko aldagaien balizko garrantziari dagokionean (Clark eta Lipset, 2001; Mayer, 2006; Norris, 2006; Rose, 2000 eta Thomassen, 2005 in Sulmont Haak 2010:16). Egun, hauteskunde portaera aztergai duten ikertzaile askok, bozka eredu honetan hauteskunde testuinguru bezala deitu dugunarengan arreta berezia ipini dute, ideologia, alderdi identifikazioa edota beste identitate sendoen eragina bigarren maila batean utziaz. Honela, aldagai makrosozialen eraginari azpimarra egiten diote (besteak beste, sistema politikoa, alderdi sistema edota hauteskunde sistema), aldagai mikrosozialen (adina, generoa, hezkuntza, klase soziala, besteak beste) eraginean ohikoa izan den begiradatik aldenduaz.

Bozka ereduan eragina duen hirugarren ardatza hauteskunde testuinguruarena litzateke beraz. EAEn bozka baldintzatzeko aldagai garrantzitsua litzateke uneko alderdi abertza- 
le/ez abertzaleen arteko indar korrelazioa. Horren adierazgarri litzateke 2001eko hauteskunde autonomikoetako ingurumaria, non alderdi espainolisten garaipen baten beldurrez, herritar askok EAJra bozka transferentzia egin zuten. Agerian geratu zen orduan balizko indar korrelazio aldaketa batek herritarrak mobilizatu zituela eta hauteskunde kanpainak eragin zuzena izan zuela.

Pallaresek 2001eko hauteskunde autonomikoez egindako analisian azken auzi honi heltzen dio. 2001ean EAJk 604.222 bozka jaso zituen, 1998an baino 150.000 bozka gehiago. Bere ustez, emaitza hauen haritik eginiko lehen interpretazioak oker zeuden; EAJk irabazitako bozka kopuru osoaren erdia besterik ez bailetorke EHtik. Ildo honetan, Pallaresek dio 80.000 bozka inguru EHko boto-emaile ohienak izan zirela, baina gainerako 70.000ak sektore moderatuetatik etorri zirela. Pallaresek sektore moderatuak aipatzen ditu eta, hauek, 2001ean EAJri bozka emateko izan zituzten arrazoi batzuk luzatzen ditu. Bere ustez, abertzaleak izan gabe ere, herritar askok EAJrengan boto segurtasun bat ikusi zuten, PP erradikal bat buru zuen gobernu batek sorrarazten zien ziurgabetasunaren aurrean. Honela, egokiagotzat ikusi zuten EAJk lideratutako gobernu bat une hartan EAEren baitan zen prozesu politikoa aurrera eramateko (Pallarés, 2002).

Guk indar abertzale/ez abertzaleen indar korrelazioaren aldagaia bakarrik aipatu badugu ere hauteskunde testuinguruak EAEn izan dezakeen eragina aztertzeko, ezin ukatu ahal dugu, gurean ere, hautagaiek, kanpainek eta hauteskunde motek ere eraginik badutela. 2015eko abenduaren 20ko emaitzei heltzen badiegu, EAEn ere hautagaien karisma edo erakargarritasunak eraginik izan dutela iradokitzen digute. Bestela, ezin uler daiteke, EAEn Podemosek izandako emaitzak, bozka gehien jaso zituen alderdia izanik, hain justu EAEko Podemosen egitura desagertu eta gero. Emaitza hauek ordea, hautagai eta alderdi berrien erakargarritasun batetik haratago aztertu behar dira, hauteskunde orokorren testuinguruan hain zuzen ere. Halere, gurean orain artean ez da ohikoa izan, edo ez hain indartsua behintzat, Katalunian eman izan ohi den bozka duala. Abenduko emaitzetatik bozka hau gurean barneratu denaren ideia ezin berretsi ahal dugu, baina era berean, hauteskunde portaera pauten aldaketa baten adierazle bilaka daiteke denboran zehar mantentzen bada.

\section{BOZKA ABERTZALEAREN ARGIBIDE-FAKTORE BATZUK}

EAEko herritarren hauteskunde portaera baldintzatu dezaketen faktore nagusiak ikusi ondoren, alderdi abertzaleen hauteskunde mobilizazioaren zenbait gako izango ditugu hizpide. Posizio sozialaz aritu garenean, jatorriak, zehazki, nortasun nazionalaren ereduak, bozkan zer nolako eragina izan zezakeen azaltzen genuen. Balio aurrepolitikoez hitzegin dugunean, nortasun nazionalaren balizko eragina aipatu dugu eta balio politiko bilakatu daitekeen heinean, nazionalismoan hain zuzen ere, bozkan eragina izan dezake. Honetaz gain, aurretik azaldu dugu ingurumaria batzuetan alderdien lehia ez dela balio politiko bakarrean oinarritzen. Irlanda, Belgika, Katalunia edo EAEri begiratuz, alderdiak ezker-eskuin ardatzean kokatzeaz gain, nazionalismoaren ardatzean ere kokatzen direla ikusi dugu 
eta hortaz, bi dimentsioetako lehia espazio baten aurrean geundeke. Ardatz hauei emaniko garrantzia ezberdina izan daiteke eta hauteskunde mota ezberdinen arabera bata ala besteari lehentasun handiagoa eman diezaioke hautesleak.

Zergatik hautesle batzuek bozka abertzalea ematen dute eta beste batzuk ez? Ze faktore indibidualek dute eragin gehien? Zer nolako eragina du nortasun nazionalaren aldarrikapenak? Eta ezker-eskuin ideologiak? Faktore sozioekonomikoek badute eragina? Galdera hauei erantzun asmoz Pérez-Nievas eta Bonetek Europa mailako zortzi alderdi nazionalisten inguruan eginiko ikerketa bateko emaitza nagusiak aipatuko ditugu (Pérez-Nievas eta Bonet, 2005).

Nortasun mobilizazioari dagokionean, EAEn eta Katalunian hizkuntza autoktonoaren erabilera hertsiki lotua dago nortasun nazionalarekin. Euren nortasun nazionala estatukoa dela adierazten dutenek, euskararen eta katalanaren ezagutza oso baxua dute eta alderantziz, euren nortasun/leialtasuna nazionala naziokoa, kasu honetan, EAE edota Katalunia, dela adierazten dutenen artean askoz handiagoa da euskararen eta katalanaren ezagutza. Halere, kontuan hartu beharrekoa da euskara eta katalanaren ezagutza maila oso bestelakoa dela. Euskal nazionalismoa eta katalandar nazionalismoa konparatuz, Conversik hizkuntza erregionala nagusia den herrialdeetan hizkuntza nazionalismo politikoaren balio nagusi bilakatzea errazagoa dela dio, eta hortaz, nortasunaren osagai indartzaile bat, Katalunia kasu (Conversi, 1997:166-182). Alderantziz, hizkuntzaren erabilera minorizatua bada, eta hortaz, herritarren arteko banaketa sor badezake, nazionalismo politikoak beste balore nagusi bat aukera dezake, hizkuntza bigarren maila batean kokatuz nortasunaren osagai indartzaile bezala, Euskal Herria kasu.

Jatorria ere nortasun mobilizazioaren baitan kokatzen dute autoreek. Izan ere, eta aurretik azaldu bezala, EAEk, Kataluniak bezala, Espainiako fluxu migratzaile handiak jaso zituen eta, bietan, jatorriak bozkan duen eragina agerikoa da. Nortasun nazional bakarra, euskal edo kataluniar nazioarena, dutela adierazten duten herritar gehienak EAEn edo Katalunian bertan jaiotakoak dira. Hortaz, autoreen arabera, jatorria ere nortasun mobilizazioaren elementua litzateke.

Pérez Nievas eta Bonetek eginiko ikerketaren emaitzen arabera, EAEko eta Kataluniako alderdi nazionalisten hauteskunde mobilizazioaren oinarrian nortasun mobilizazioa eta lurralde mobilizazioa leudeke. Alderdi nazionalistak, nortasun mobilizazioaz gain, lurraldean ere oinarritu dira. Alderdi nazionalisten aldarrikapen nagusienetako bat autogobernu mota ezberdinekin loturiko estatuaren boterearen lurralde berrantolaketa bat izan ohi da (Türsan, 1998:6). Aldarrikapen nazionalistatetan nagusi den autogobernu eskaera nortasun mobilizazioarekin hertsiki lotua egon daiteke. Kasu hauetan, autogobernuak talde minoritarioaren empowerment bitarteko gisa funtzionatzen du eta, bere aldarrikapena talde nazionala bezala aurkezten den gutxiengo taldearen existentziaren bitartez legitimatzen da.

Aztergai izan dituzten alderdi ezberdinei erreparatuz, nortasun eta lurralde mobilizaziotik haratago, Pérez Nievas eta Bonetek eginiko ikerketaren emaitzen arabera, CIUren kasuan bakarrik ikus dezakegu eragin gehiago duen beste faktore bat, boto-emaileen kokapen ideo- 
logikoa, hain zuzen ere. Ezker-eskuin ardatzak badu eragina kasu honetan, eta boto-emaileak eskala ideologikoan gero eta eskuinerago kokatuz, koalizioa bozkatzeko aukera gehiago dute. Ikerketa honen arabera gainera, ERCren kasuan nazio identitateak eta kokapen ideologikoak pareko eragina izango luke. EAJ/EAren kasuan aldiz, ideologiak ez luke pisurik izango bozkan. Gainera, CIUk boto-emaileak lurralde eta autogobernuaren aldeko argudioei helduz mobilizatzen dituen bitartean, ERC eta EAJ/EAri dagokionean, nortasun nazionalari erreparatuko diete. Dena den, ERCren kasuan, nortasunek kokapen ideologikoaren adineko indarra dute. Aipatzekoa da ere, ERC alderdia dela bere hautesleak bi faktoreen bidez mobilizatzen dituen bakarra: nortasuna eta lurraldearentzako autogobernu aldarrikapena.

Hizpide ditugun lurralde eta nortasun mobilizazioetatik haratago, beste faktore batzuek ere eragiten dute bozka abertzalean: CIU eta EAJ/EAren (azken honi autonomikoetan) bozka ohikoagoa da gizonezkoen artean. ERCrena aldiz, gazteen artean. Estratifikazio sozialaren aldagaiei dagokionean, eragina CIUn bakarrik ikusi ahal izan da, eskulangile kualifikatuek koalizioari bozka emateko probabilitate gutxiago dute inoiz enplegurik izan ez dutenekin alderatuz. Bestalde, katoliko bezala definitzeak efektu baikorrak ditu CIUren bozkan hauteskunde orokorretan, eta EAJ/EAn hauteskunde autonomikoetan. Edozein kasutan, generoa, adina, erlijioa eta ezaugarri sozioekonomikoak ahulagoak dira bozka abertzalea azaltzeko nortasun edo/eta autogobernu aldarrikapenak baino, eta CIU eta ERCren kasuan, kokapen ideologikoa baino.

EAJ/EA eta ERC dira nortasun mobilizazioa agerikoen duten alderdiak eta hain justu, alderdi hauek dira hauteskunde deialdi ezberdinetan fideltasun gehien duten alderdiak. Lipset eta Rokkanek azaltzen duten bezala (1967), politikan auzi eta arazo berriak sortzen badira ere, gizarte egiturako banaketa klasiko eta lerrokatzeak oso astiro aldatzen dira. EAE eta Kataluniako ingurumaria politikoetan, jatorritik eratorritako nortasun nazionala banaketa ardatz esanguratsua da, eta leialtasun estuko atxikimendu politikoa adierazten dute egun ere. Hiru alderdi hauetako boto-emaileek fideltasun handia erakusten dute; CIUkoen boto leialtasuna aldiz, erdi mailakoa dela esan genezake.

Katalunian deialdi motaren arabera ikusten diren emaitza ezberdinak bi portaera indibidualen araberakoak izan daitezke. Bata, deialdiaren arabera alderdi nazionalista eta estatu mailako alderdien artean ematen den bozka transferentzia (PSC eta CIUren artekoa bereziki), bozka duala deritzaiona eta, bigarrena, hauteskunde autonomikoetan, orokorrekin alderatuz, eman ohi den abstentzio maila altuagoa, bereziki espainiar nortasuna azaltzen duten boto-emaileen artean (Montero eta Font, 1989,1991; Pallarés eta Font, 1994 in Pérez-Nievas eta Bonet, 2005:140). EAEn ere alderdi nazionalistek emaitza hobeagoak izaten dituzte hauteskunde autonomikoetan baina bozka dual horrek, Katalunian ez bezala, EAEn orain artean eragin urriagoa izan duela esateko moduan gaude.

Aurretik azaldu dugu hauteskunde portaerari buruzko ikerketa berriek posizio eta balio politikoekin harremanduriko aldagaien eragina auzitan ipintzen dutela, halere, gurea bezalako ingurumaria politikoan eragin zuzena dutela esateko moduan gaude. Oinarrian izan dugun bozka ereduan kokatuaz, EAEko herritarren hauteskunde portaera aztertzean nazio- 
nalismoaren ardatzaren araberako bozka aukera gailentzen denaren ideia berresten dugu. Aldiz, eredu arrazionalaren ereduarekin loturiko bozka pautak, edota testuinguru politikoa edota faktore makrosozialek ez lukete hainbeste eragin handiegirik. Halere, ezin ukatu ahal dugu Podemosen sarrerak tesi hau stand by egoeran utzi dezakeela, eta, posible da hortaz, gurean hauteskunde portaeraren klabe nagusienen aldaketa baten aurrean aurkitzea.

\section{INDEPENDENTZIAREN ALDEKO HAUTUAN ERAGIN DEZAKETEN FAKTOREAK AZTERGAI, KATALUNIAREN ADIBIDEA}

EAEko herritarren hauteskunde portaera hizpide izan dugunean, nortasun nazionala eta nazionalismoari erreparatu diegu. Determinanteak izan gabe ere, alderdi abertzaleen mobilizazio iturri nagusiak klabe horietan kokatzen dira eta herritarren nortasun subjektiboak eta abertzaletasun mailak eragin handia du hauteskunde hautuan. Artikulu honen helburu nagusia EAEn alderdi abertzaleek jasotzen duten bozka eta independentismoaren arteko harremana aztertzea da, baina azterketa enpirikoari erreparatuko aurretik, Kataluniako egoera izango dugu hizpide.

Ivan Serranok (2013) Kataluniako herritarren parte batek independentzia/sezesioaren aldeko hautuaren nondik norakoei erreparatzen die eta estatu deszentralizatu baten baitan biztanleriaren zati batek independentzia edota sezesioa babestearen arrazoiak aztertu ditu, horretarako bi dimentsio hauek kontuan izanik: nortasunarena eta ongizateari dagokiona.

Nortasunaren dimentsioari begira, datuek agerian uzten dute nortasun subjektiboa eta lehenetsitako estatu ereduaren/antolaketaren harremana oso estua dela. Halere, kontuan hartu behar da harreman hori ematen duena baino konplexuagoa dela eta erpin ugari dituela (Pattie et al., 1999:309; MacCrone eta Paterson, 2002; Paterson, 2003; Johns et al., 2009:211 in Serrano, 2013:526). Nortasun nazionala era ezberdinean definitua izan daiteke; Serranok, nortasun nazionala ardatz sozialean gizanakoek duten posizio indibiduala bezala ulertzen du. Posizio hori, sozializazio faktore ezberdinen konbinazio eta interakziotik sortzen da. Almond eta Verba (1989) edota Lipset eta Rokkanek (1992) azpimarratu bezala, posizio sozialak, ez daude beti politizatuak, eta hortaz, adierazpen eta intentsitate politiko ezberdinak har ditzakete. Ondorioz, ezin dugu nortasun subjektiboa nazionalismoaren adierazletzat hartu zuzenean, gizabanakoen identifikazio horiek jarrera eta lehentasun politikoetan nola islatzen diren aztertu beharko da. Nortasun nazionala, ingurumaria konkretu batean aktibatua izan daiteke, baina horrek ez du zertan eragin zuzena izan behar banaketa edo independentziaren aldeko jarreretan (Hale, 2008:39). Hau da, nazio identitatearen indartzea ez da zertan islatu behar, edo ez maila berean, herritarren estatu egituraren edo ereduaren inguruko hautuan.

Estaturik gabeko nazioak konparatuz, nortasuna eta independentziaren aldeko hautuaren babesaren arteko harreman eredu ezberdinak ikus ditzakegu. Katalunian azken urteetan autogobernua eta independentziaren aldeko jarrerak handitu egin dira, nazio identifikazioaren egitura maila berean aldatu ez bada ere. Eta hortaz, beste aldagai batzuk ere kon- 
tuan izan beharko dira independentismoaren gorabeheren nondik norakoak aztertzeko orduan. Hauteskunde datuei erreparatuz, Katalunian, independentziaren hautua babesten duen \%56ak bakarrik bozkatu ohi die alderdi abertzaleei. Bestalde, alderdi abertzaleei bozka ematen dien \%24ak ez du independentzia babesten. Hortaz, bozka ezin da ardatz edo auzi bakar batera mugatu eta dimentsio ezberdinak aztertu beharko dira.

Kataluniako independentziaren aldeko jarrerak aztertzeko, bigarren dimentsio bat ere aztertu behar dugu, ongizatearena. Estaturik gabeko nazioetako diskurtso nazionalistek ongizateari ere egiten diete erreferentzia, sezesioaren onura politiko eta ekonomikoak azpimarratuz. Nazionalismoak izaera bikoitza duenaren tesian kokatu beharko genuke hortaz Kataluniako ingurumaria, non osagai emozionalak eta instrumentalak uztartuko liratekeen (Máiz, 2003:208). Diskurtso nazionalistek, auzi etnokulturalez gain, independentziak ekar litzakeen ongizate politika hobeak eta herritarrekiko gertuagoko gobernuei men egiten diete (Sorens, 2005:307).

Serranok eginiko ikerketaren arabera, Katalunian independentziaren alde azaldu direnen \%63,5ak ongizatearekin zerikusia duten argudioak luzatzen dituzte eta, \%25,4ak bakarrik erreparatzen dio Kataluniaren nazio izaerari edota bere nortasun subjektiboari, \%82,9a katalana bakarrik edo katalana gehiago bezala definitu arren. Hortaz, ezin uka daiteke katalana bakarrik edo katalana gehiago bezala definitzeak lotura estua duela independentziaren babesarekin, baina hautu hau adierazten dutenak, nortasun irizpideak baino, ongizatearekin loturiko argudioei heltzen diete. Datu hauei helduaz, zenbait azterketek Kataluniako independentziaren aldeko hautuan nortasunak duen eragina gutxietsi dute, independentziaren alde agertzen direnen argudio funtzionalista edota argudio ez identitarioei helduaz. Halere, ezin ahantzi ahal dugu argudio bat edo bestea luzatu, aldekotasun hori nortasun konkretu bat dutenengana mugatzen dela.

Laburbilduz, nortasun nazionala, ingurumaria konkretu batean aktibatua izan daiteke, baina horrek ez du zertan eragin zuzena izan behar banaketa edo independentziaren aldeko jarreretan. Berdina esan dezakegu hauteskunde portaera oinarrian harturik, hau da, alderdi abertzaleen bozka kopuruak ez du zertan independentziaren aldeko jarreretan eraginik izan behar. Kataluniako datuek agerian uzten dute bi parametroak ezberdintzearen beharra.

\section{ALDERDI ABERTZALEEN BOZKA ETA INDEPENDENTIS- MOAREN ARTEKO HARREMANA EAEN (1994-2013)}

Katalunian independentziaren inguruko hautuan nortasunaren dimentsioak eta ongizateraen dimentsioak duen indarra izan dugu hizpide. Jarraian, EAEn bozka abertzalea eta independentismoaren arteko harremanaren nondik norako nagusiei helduko diegu. Alderdi abertzaleen bozka eta independentzia nahien arteko harremana aztertzeko, 1994tik aurrera izandako hauteskunde autonomikoak izan ditugu oinarrian ${ }^{1}$. Hauteskunde hauen ondotik, urte hauetan bertan herritarrek azaldutako independentzia nahiak azalduko ditugu, elkarren arteko harremana edo tartea nolakoa den ikusteko. Horretarako, Euskoba- 
rometroaren serieak izan ditugu oinarrian. Hauteskunde autonomikoen urtea eta inkesta urteak ez datoz beti bat, baina hizpide izango dugun inkesta guztiak hauteskunde autonomiko horietako bozka oroitzapenak dituzte erreferentziatzat. Esaterako, 1995eko inkestan herritarrek azaltzen dituzten independentzia nahiak 1994ko bozka oroitzapena kontuan harturik aztertu ditugu.

\subsection{4ko hauteskunde autonomikoak}

Lehenik eta behin, 1994ko hauteskunde autonomikoetan alderdi abertzaleek jasotako bozka kopuruari egingo diogu erreferentzia. Hauteskunde hauetan alderdi abertzaleek 575.629 bozka jaso zituzten. Bozka kopuru honek boto baliodunaren \%55,5a suposatzen du. Errolda osoa aintzat hartuko bagenu, \%32,9a.

Taula 4.1. Alderdi abertzaleek jasotako bozka kopurua (boto baliodunarekiko eta erroldarekiko \%) (1994)

\begin{tabular}{llll} 
& Bozka & Boto balioduna (\%) & Errolda (\%) \\
EAJ & 304.346 & 29,3 & 17,4 \\
\hline HB & 166.147 & 16,0 & 9,5 \\
\hline EA & 105.136 & 10,1 & 6,0 \\
\hline Bozka abertzalea & 575.629 & 55,5 & 32,9 \\
\hline Guztira & 1.044 .085 & 1.037 .901 & 1.749 .250 \\
\hline
\end{tabular}

Iturria: Eusko Jaurlaritza. Hauteskundeeetako Emaitzen Artxiboa.

1995eko inkestari heltzen badiogu, independentzia nahi handiak adierazten dituztenen ehunekoa \%30,9koa dela ikus genezake. Hortaz, agerikoa da alderdi abertzaleek jasotzen duten bozka kopurua (\%55,5), independentzia nahi handiak azaltzen dituzten herritarrena baino handiagoa dela. Bozka abertzalea ezin parekatu ahal dugu sentimendu independentistarekin; askoz gehiago dira alderdi abertzaleei bozka ematen dietenak, independentistak baino.

Taula 4.2. Independentzia nahiak 1994ko auteskunde automikoetarako bozka oroitzapenaren arabera (1995)

\begin{tabular}{llllllll} 
& EAJ & EA & HB & IU/EB & PSE/EE & PP & Guztira \\
Nahi handiak & 50,4 & 65,3 & 95,0 & 22,2 & 4,1 & 6,0 & 30,9 \\
\hline Nahi txikiak & 17,7 & 18,4 & 1,0 & 27,8 & 29,3 & 22,0 & 20,5 \\
\hline Batere ez & 13,4 & 2,0 & 1,0 & 23,6 & 50,3 & 68,0 & 26,3 \\
\hline Axolagabe & 8,6 & 12,2 & 2,0 & 22,2 & 7,5 & 0,0 & 10,1 \\
\hline Ed/Ee & 9,9 & 2,0 & 1,0 & 4,2 & 8,8 & 4,0 & 12,1 \\
\hline Guztira & 100 & 100 & 100 & 100 & 100 & 100 & 100 \\
\hline
\end{tabular}

Iturria: Euskobarometroa (1995). 
Bozka abertzalea eta sentimendu independentistaren arteko jauzia agerian geratzen da alderdi abertzaleei bozka eman zieten herritarren independentzia nahiak aztertzean. 1995. urteko datuak azterturik, independentzia nahiei dagokienean, \%30,9ak independentzia nahi handiak azaltzen ditu, \%20,5ak independentzia nahi txikiak eta \%26,3ak banaketarako inongo gogorik ez duela azaltzen du. Alderdi abertzaleei bozka eman diotela azaltzen dutenen artean banaketaren aldeko jarrera aurkako jarrera azaltzen dutenena baino handiagoa da. Dena den, alderdi abertzaleei bozka ematen diotenen artean bada ezberdintasunik independentzia nahiei dagokionean.

Honela, 1994ko hauteskunde autonomikoetan EAJri bozka eman ziola adierazten duen \%50,4ak independentzia nahi handiak azaltzen ditu; \%30,9ak aldiz, nahi txikiak $(\% 17,6)$ edota batere independentzia nahirik ez duela azaltzen du (\%13,3). EAri bozka eman ziola adierazi duen \%65,3ak azaltzen ditu independentzia nahi handiak; \%20,3ak aldiz, independentzia nahi txikiak (\%18,3) edota batere nahirik ez duela azaltzen du (\%2). HBri bozka eman ziotenak dira independentzia nahi handiak gehien azaltzen dituztenak (\%95) eta \%2ak bakarrik azaltzen du nahi txikiak (\%1) edota batere nahirik ez duela (\%1). Bozka abertzalea eta sentimendu independentistaren arteko jauzia nabaria da EAJko boto-emaileengan, EAJ alderdiaren boto-emaileen erdiek soilik azaltzen dituzte independentzia nahi handiak (ikus 4.1. Grafikoa).

Grafikoa 4.1. 1994ko hauteskunde autonomikoetan alderdi abertzaleei bozka eman zietenen independendentzia nahi handiak (1995)

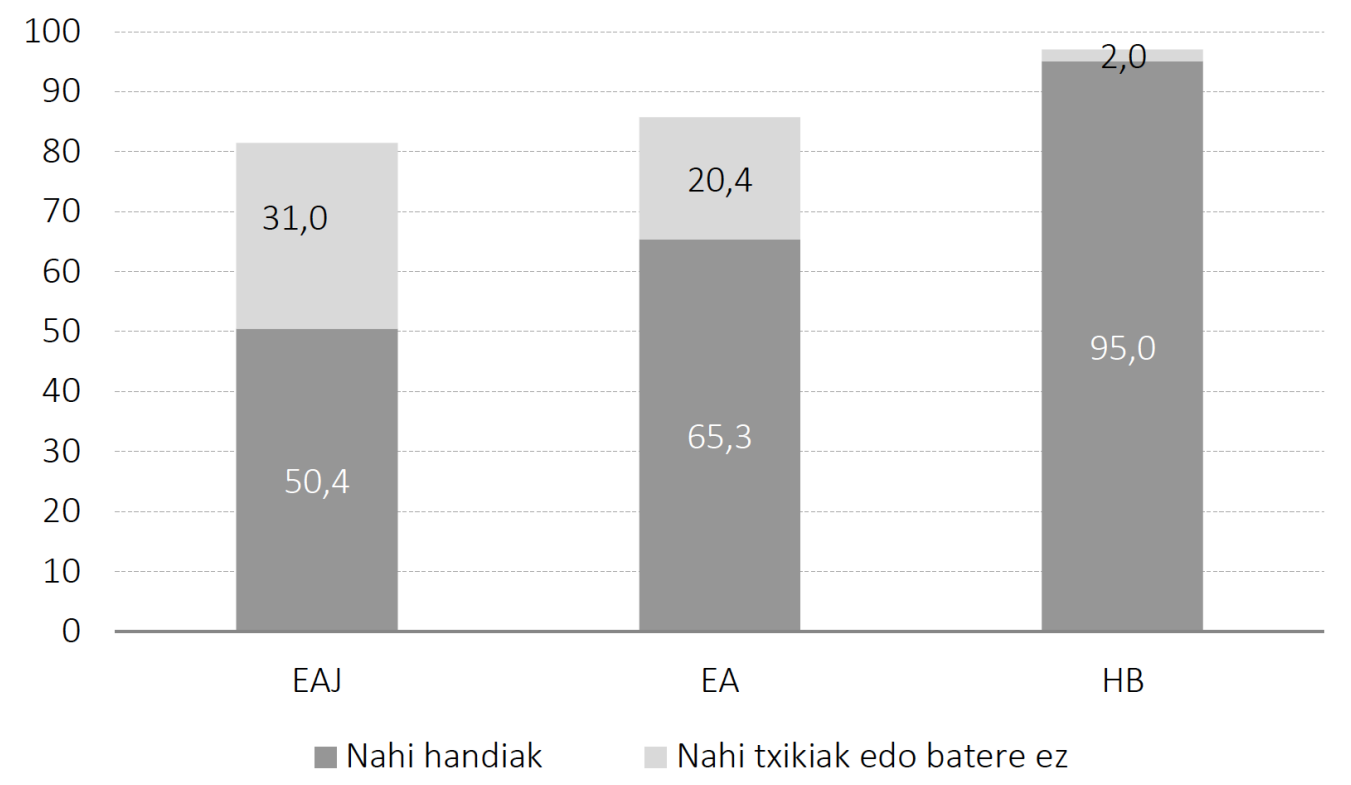

Iturria: Euskobarometroa (1995).

\subsection{8ko hauteskunde autonomikoak}

1998ko hauteskunde emaitzei erreparatuz, alderdi abertzaleek 682.958 bozka jaso zituzten; boto baliodunaren \%53,9a eta errolda osoaren \%37,5a. 1999an herritarren \%39,8ak azaltzen zituen independentzia nahi handiak. Hortaz, berriro ere bozka abertzalea sentimendu independentista baino handiagoa dela ikus dezakegu. 
Taula 4.3. Alderdi abertzaleek jasotako bozka kopurua (boto baliodunarekiko eta erroldarekiko (1998)

\begin{tabular}{lccc} 
& Bozka & Boto balioduna(\%) & Errolda(\%) \\
EAJ & 350.322 & 27,6 & 19,2 \\
\hline EH & 224.001 & 17,7 & 12,3 \\
\hline EA & 108.635 & 8,6 & 6,0 \\
\hline Bozka abertzalea & 682.958 & 53,9 & 37,5 \\
\hline Guztira & 1.275 .008 & 1.268 .206 & 1.821 .608 \\
\hline
\end{tabular}

Iturria: Eusko Jaurlaritza. Hauteskundeeetako Emaitzen Artxiboa.

1999ko inkesta datuei erreparatuz, alderdi abertzaleei bozka eman dietela azaltzen dutenen artean banaketaren aldeko jarrera nagusitzen da, 1995eko datuekin alderatuz independentzia nahi txikiak adierazten dituztenen ehunekoa handituz badoa ere. Dena den, alderdi abertzaleei bozka ematen dietenen artean ere bada ezberdintasunik independentzia nahiei dagokienean.

Taula 4.4. Independentzia nahiak 1998ko hauteskunde autonomikoetako bozka oroitzapenaren arabera (1999)

\begin{tabular}{llllllll} 
& EAJ & EA & EH & IU/EB & PSE/EE & PP & Guztira \\
Nahi handiak & 48,8 & 52,4 & 91,3 & 20,3 & 12,3 & 12,2 & 39,8 \\
\hline Nahi txikiak & 37,2 & 36,9 & 3,3 & 48,4 & 48,0 & 40,9 & 32,6 \\
\hline Batere ez & 6,9 & 3,6 & 1,1 & 21,9 & 30,4 & 44,3 & 16,5 \\
\hline Axolagabe & 3,8 & 3,6 & 1,1 & 6,3 & 8,2 & 1,7 & 7,3 \\
\hline Ed/Ee & 3,4 & 3,6 & 3,3 & 3,1 & 1,2 & 0,9 & 3,9 \\
\hline Guztira & 100 & 100 & 100 & 100 & 100 & 100 & 100 \\
\hline
\end{tabular}

Iturria: Euskobarometroa (1999).

1998ko hauteskunde autonomikoetan EAJri bozka eman ziola adierazten duen \%48,8ak independentzia nahi handiak azaltzen ditu; \%44,1ak aldiz, nahi txikiak $(\% 37,2)$ edota batere independentzia nahirik ez duela azaltzen du $(\% 6,9)$. EAri bozka eman ziola adierazi duen \%52,4ak azaltzen du independentzia nahi handiak; \%40,5ak aldiz, independentzia nahi txikiak $(\% 36,9)$ edota batere ez duela azaltzen du (\%3,6). EH koalizioari bozka eman ziotenak dira independentzia nahi handiak gehien azaltzen dituztenak $(\% 91,3)$.

Grafikoa 4.2. 1998ko hauteskunde autonomikoetan alderdi abertzaleei bozka eman zietenen independendentzia nahi handiak (\%)

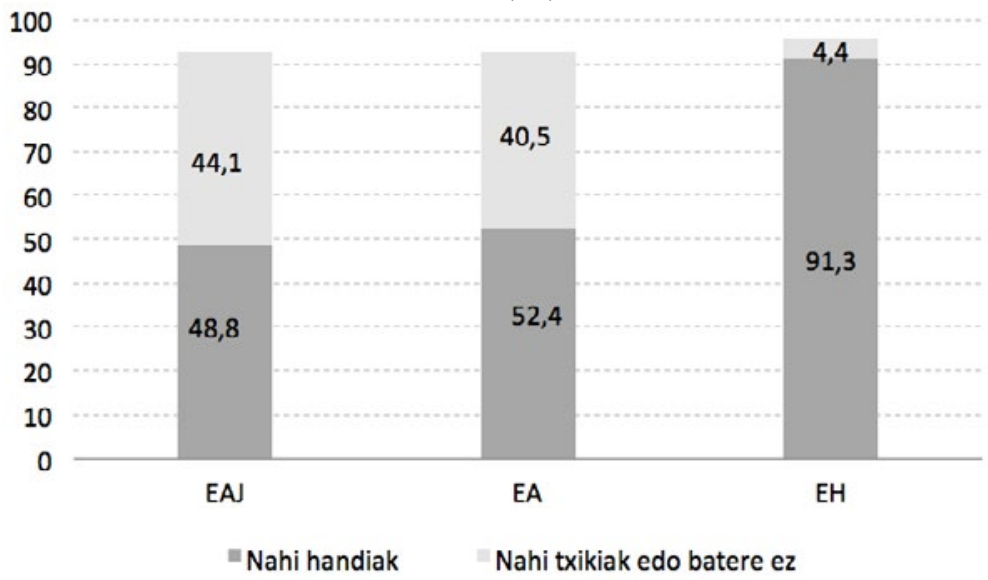


Alderdi abertzaleek jasotako bozka hortaz, ez litzateke sentimendu independentistaren adierazle. Dena den, eta 1995eko inkestan ikusi bezala, bozka abertzalea eta sentimendu independentistaren arteko desakordioa, bereziki, EAJri bozka eman ziola adierazten dutenen artean ematen da. EAJren boto-emaileen erdia da independentzia nahi handiak erakusten dituena, EHren boto-emaileen gehiengo zabala aldiz, independentista litzateke. EHren kasuan hortaz, bozka eta sentimendu independentista uztartzen direla ikus genezake.

\subsection{1eko hauteskunde autonomikoak}

2001eko hauteskunde autonomikoetan alderdi abertzaleek orain artean jasotako bozka kopuru handiena jaso zuten: 747.361 bozka. Halere, eta egon zen hauteskunde partehartzea medio, boto baliodunaren gaineko ehunekoa aurreko urteetakoaren antzekoa da $(\% 52,4)$. Bestalde, azterturiko urteetan, errolda osoarekiko azken urteetako pisu handiena $(\% 41,2)$ lortu zuen bozka abertzaleak.

Taula 4.5. Alderdi abertzaleek jasotako bozka kopurua (boto baliodunarekiko eta erroldarekiko \%) (2001)

\begin{tabular}{llll} 
& Bozka & Boto balioduna(\%) & Errolda(\%) \\
EAJ/ EA & 604.222 & 42,4 & 33,3 \\
\hline EH & 143.139 & 10,0 & 7,9 \\
\hline Bozka abertzalea & 747.361 & 52,4 & 41,2 \\
\hline Guztira & 1.431 .996 & 1.425 .777 & 1.813 .356 \\
\hline
\end{tabular}

Iturria: Eusko Jaurlaritza. Hauteskundeeetako Emaitzen Artxiboa.

2001ean independentzia nahi handiak azaltzen dituztenen kopurua aldiz, aztergai dugun serie honetako txikiena da (\%25,2). Nola esplikatu ahal da 2001ean ematen den bozka abertzalea eta sentimendu independentistaren arteko jauzi hau? 2001eko hauteskunde testuingurua berezia izan zen, eta alderdi espainolisten garaipenaren beldur edo mehatxuak, boto-emaileak mobilizatu zituen. Ondorioz, EAJ/EA koalizioak aurretik Ezker Abertzaleari bozka eman ziotenen bozka ere jaso zuen eta boto-emaile desmobilizatuak ere hautesontzietara hurbildu ziren. Gureak irabaz dezatela leloak laburbildu ahal du bozka abertzalearen gorakada. Gureak hori ez bada ere sentimendu independentista, eta aurrerago ikusiko dugun bezala, abertzaletasunarekin parekatu behar. Paradoxikoki gainera, 2001. urtean independentzia nahi handiek inoiz izan duten babes baxuena lukete.

Taula 4.6. Independentzia nahiak 2001eko hauteskunde autonomikoetako bozka oroitzapenaren arabera (2001)

\begin{tabular}{lllllll} 
& EAJ/EA & EH & IU/EB & PSE-EE & PP & Guztira \\
Nahi handiak & 39,9 & 77,1 & 15,0 & 2,6 & 1,6 & 25,2 \\
\hline Nahi txikiak & 37,4 & 21,4 & 50,0 & 48,2 & 39,1 & 37,6 \\
\hline Batere ez & 7,2 & 0,0 & 18,3 & 36,0 & 50,0 & 16,9 \\
\hline Axolagabe & 8,1 & 0,0 & 13,3 & 11,4 & 6,3 & 10,0 \\
\hline Ed/Ee & 7,4 & 1,4 & 3,3 & 1,8 & 3,1 & 10,3 \\
\hline Guztira & 100 & 100 & 100 & 100 & 100 & 100 \\
\hline
\end{tabular}


2001eko datuei erreparatuz, herritarren independentzia nahi handiak txikitzen direla ikus genezake. Herritarren \%25,2ak independentzia nahi handiak azaltzen ditu; \%54,5ak aldiz, independentzia nahi txikiak (\%37) edota batere nahirik ez duela azaltzen du (\%17). Independentzia nahi handien txikitzea 2001eko hauteskunde autonomikoetan aurkeztu ziren bi koalizio abertzaleen boto-emaileengan nabari da (ikus.4.3. Grafikoa).

Grafikoa 4.3. 2001eko hauteskunde autonomikoetan alderdi abertzaleei bozka eman zietenen independendentzia nahi handiak (2001)

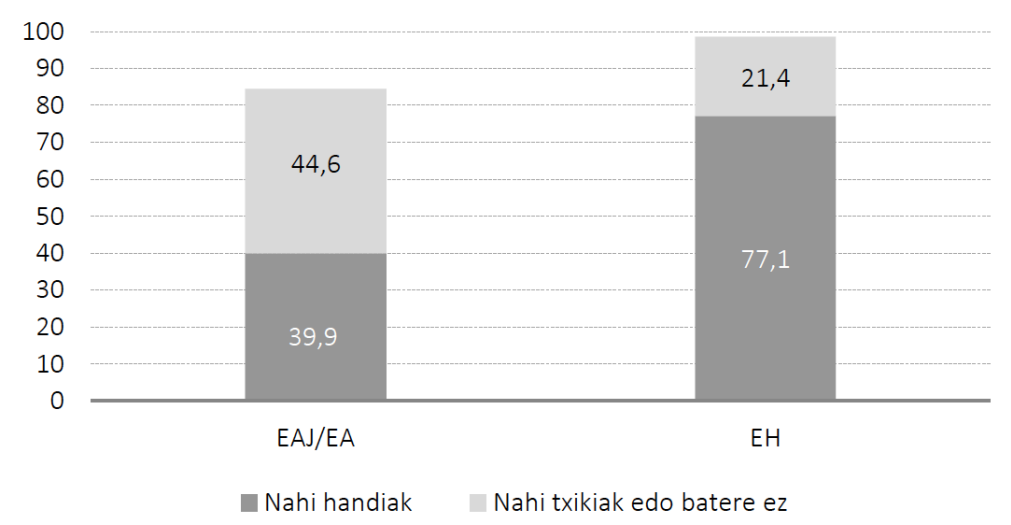

Iturria: Euskobarometroa (2001)

Alderdi abertzale ezberdinei bozka eman zietela azaltzen duten herritarrei erreparatuz, agerikoa da bozka abertzalea eta sentimendu independentistaren arteko jauzia. EAJ/EAri bozka eman ziola adierazi duten herritarren artean gehiago dira independentzia nahi txikiak $(\% 37,4)$ edo batere nahirik ez dutela azaltzen dutenak $(\% 7,2)$, independentzia nahi handiak azaltzen dituztenak baino (\%39,9ak). Ezin dugu ahantzi gainera, 2001ean EA, EAJ alderdiarekin aurkeztu zela hauteskunde autonomikoetara, eta honek, EAJ/EA koalizioari independentzia nahi handiak dituztenen boto-emaileen handitzea ekarri duela uler dezakegula. Baina aurretik azaldu bezala, 2001ean EAJ/EA koalizioak beste boto-emaile mota bat ere erakarri zuen. Ezker Abertzaleari bozka eman ziotenen artean ere zertxobait txikitzen da independentzia nahi handiak azaltzen dituztenen ehunekoa.

\subsection{5eko hauteskunde autonomikoak}

2005eko hauteskundeetako datuek 1998ko argazki beretsua erakusten digute. Alderdi abertzaleek 646.941 bozka jaso zituzten, boto baliodunaren \%53a.

Taula 4.7. Alderdi abertzaleek jasotako bozka kopurua (boto baliodunarekiko eta erroldarekiko \%) (2005)

\begin{tabular}{llll} 
& Bozka & Boto balioduna(\%) & Errolda(\%) \\
EAJ/EA & 468.117 & 38,4 & 26,0 \\
\hline EHAK & 150.644 & 12,4 & 8,4 \\
\hline ARALAR & 28.180 & 2,3 & 1,6 \\
\hline Bozka abertzalea & 646.941 & 53,0 & 36,0 \\
\hline Guztira & 1.223 .634 & 1.219 .599 & 1.799 .500 \\
\hline
\end{tabular}

Iturria: Eusko Jaurlaritza. Hauteskundeeetako Emaitzen Artxiboa 
Sentimendu independentistari dagokionean, herritarren \%37,9ak azaltzen ditu independentzia nahi handiak eta hortaz, 1998ko tarte beretsua ikus dezakegu bozka abertzalea eta sentimendu independentista azaltzen dutenen artean.

2005eko datuak 2001ekoekin alderatzen baditugu, herritarren independentzia nahi handiak handitzen direla ikus genezake. 2005ean herritarren \%37,9ak independentzia nahi handiak azaltzen ditu; \%51,6ak aldiz, independentzia nahi txikiak (\%30) edota independentziarako batere nahirik ez duela azaltzen du (\%21,6). 2005ean bada aldaketarik; batetik, alderdi abertzale berri bat aurkezten da hauteskunde autonomikoetara, Batasuna alderdia utzi ondoren eratzen den Aralar alderdia, hain zuzen ere. Bestetik, Batasunaren ilegalizazioaren ondoren, Ezker Abertzalea EHAK alderdiaren bidez aurkeztuko da hauteskundeetara.

Taula 4.8. Independentzia nahiak 2005eko hauteskunde autonomikoetako bozka oroitzapenaren arabera (2005)

\begin{tabular}{llllllll} 
& EAJ/EA & Aralar & EHAK & IU/EB & PSE/EE & PP & Guztira \\
Nahi handiak & 58,4 & 80,8 & 97,2 & 28,1 & 0,0 & 1,8 & 37,9 \\
\hline Nahi txikiak & 24,6 & 11,5 & 0,9 & 46,9 & 47,7 & 10,9 & 30,0 \\
\hline Batere ez & 7,3 & 0,0 & 0,0 & 14,1 & 50,0 & 87,3 & 21,6 \\
\hline Axolagabe & 2,5 & 7,7 & 0,0 & 10,9 & 0,0 & 0,0 & 4,5 \\
\hline Ed/Ee & 7,3 & 0,0 & 1,9 & 0,0 & 2,3 & 0,0 & 6,0 \\
\hline Guztira & 100 & 100 & 100 & 100 & 100 & 100 & 100 \\
\hline
\end{tabular}

Iturria: Euskobarometroa (2005).

Independentismoari dagokionean, alderdi abertzaleei bozka ematen dieten herritarrek 1999ean erakutsitako jarrera beretsua erakusten dute. Modu honetara, alderdi abertzaleei bozka eman dietela azaltzen duten herritar gehienek banaketaren aldeko jarrera erakusten dute. Hori bai, alderdi abertzale ezberdinetako boto-emaileen artean ezberdintasunak ikus ditzakegu.

Grafikoa 4.4. 2005eko hauteskunde autonomikoetan alderdi abertzaleei bozka eman zietenen independendentzia nahi handiak (2005)

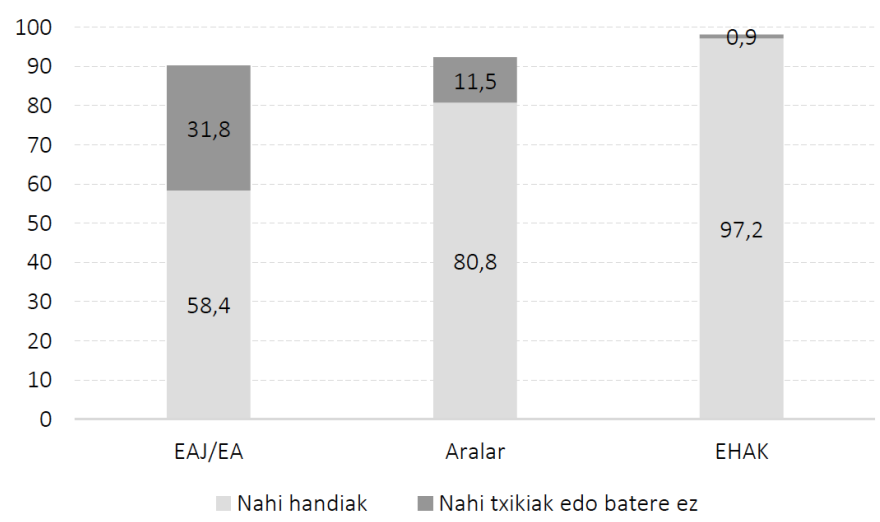

Iturria: Euskobarometroa (2005).

Honela, EAJ-EAri bozka eman diola azaltzen duten herritarrak dira, gehiengoa izanik ere, banaketaren aldeko jarrera era lausoenean azaltzen dutenak. \%58,4k independentzia nahi handiak azaltzen ditu, \%31,9ak aldiz, nahi txikiak $(\% 24,6)$ edota batere nahirik ez due- 
la azaltzen du (\%7,3). Aralarreko boto-emaileen gehiengo zabalak independentzia nahi handiak azaltzen ditu $(\% 80,8)$. Banaketaren aldeko jarrera hau are eta nabarmenagoa da EHAKren boto-emaileen artean (\%97,2). Berriro ere, EAJ (hauteskunde hauetan EArekin koalizioan aurkeztua) eta nazionalismo instituzionala ordezkatzen duen alderdi edo koalizioak jasotako bozka, sentimendu independentistaren adierazle ez dela agerian geratzen da (ikus 4.4. Grafikoa).

\subsection{9ko hauteskunde autonomikoak}

2009ko datuei heldu aurretik kontuan izan beharreko bi faktore aipatu behar ditugu. Batetik, Ezker Abertzalea ordezkatzen duen Batasuna alderdia legez kanpo dago eta D3M hautagaitza aurkeztu bazuten ere, hau ere legez kanporatua izango da eta hortaz, hautagaitza honek jasotako bozkak baliogabetuak izan ziren. Bestetik, eta azken urteetan ez bezala, EA alderdia ez da EAJrekin koalizioan aurkeztuko hauteskunde autonomikoetara.

2009an 100.000 boto baliogabe izan ziren, eta, boto baliogabea normalean 5.000-6.000 inguruan kokatzen denez, baliogabetua izan zen D3M hautagaitzari 95.000 bozka inguru egotzi dizkiogu. Guztira, alderdi abertzaleek 595.312 bozka jaso zituzten, boto baliodunaren \%56,8a eta erroldaren \%33,5a. Sentimendu independentistari dagokionean, 2009ko inkestan EAEko herritarren \%30,5ak azaltzen ditu independentzia nahi handiak (ikus 4.10. taula).

Taula 4.9. Alderdi abertzaleek jasotako bozka kopurua (boto baliodunarekiko eta erroldarekiko \%) (2009)

\begin{tabular}{llll} 
& Bozka & Boto balioduna(\%) & Errolda(\%) \\
EAJ & 399.600 & 38,1 & 22,5 \\
\hline Ezker Abertzalea & 95.000 & 9,1 & 5,3 \\
\hline ARALAR & 62.514 & 6,0 & 3,5 \\
\hline EA & 38.198 & 3,6 & 2,2 \\
Bozka abertzalea & 595.312 & 56,8 & 33,5 \\
\hline Guztira & 1.148 .697 & 1.047 .758 & 1.776 .059 \\
\hline
\end{tabular}

Iturria: Eusko Jaurlaritza. Hauteskundeeetako Emaitzen Artxiboa.

2005eko datuekin alderatuz, independentzia nahi handiak azaltzen dituzten herritarren ehunekoa zertxobait txikitzen dela ikus dezakegu (\%30,5). Jaitsiera honek ez du eragiten alderdi abertzale guztietako herritarren independentzia nahietan. Honela, EAJri dagokionean, nabarmen txikitzen da independentzia nahi handiak azaltzen dituztenen ehunekoa, eta independentzia nahi txikiak edota batere nahirik azaltzen ez dutenen ehunekoa aldiz, handitu egiten da. Beherakada honetan eragina izango du orohar herritarren independentzia nahi handiak izandako txikitzeak, baina ziurrenik EA bere kabuz aurkezteak ere eragina izango du, EAren boto-emaileen artean independentziaren aldeko babesa handiagoa den heinean. 
Taula 4.10. Independentzia nahiak 2009ko hauteskunde autonomikoetako bozka oroitzapenaren arabera (2009)

\begin{tabular}{lllllllll} 
& EAJ & EA & Aralar & $\begin{array}{l}\text { Ezker } \\
\text { Abertzalea } \\
\text { (Baliogabetua) }\end{array}$ & IU/EB & PSE/EE & PP & Guztira \\
Nahi handiak & 37,5 & 56,5 & 63,4 & 96,1 & 0,0 & 4,4 & 4,7 & 30,5 \\
\hline Nahi txikiak & 38,2 & 21,7 & 19,5 & 1,3 & 53,1 & 36,1 & 18,6 & 32,2 \\
\hline Batere ez & 10,8 & 8,7 & 6,1 & 0,0 & 28,1 & 50,3 & 67,4 & 22,4 \\
\hline Axolagabe & 5,9 & 13,0 & 8,5 & 1,3 & 18,8 & 7,7 & 9,3 & 10,2 \\
\hline Ed/Ee & 7,6 & 0,0 & 2,4 & 1,3 & 0,0 & 1,6 & 0,0 & 4,7 \\
\hline Guztira & 100 & 100 & 100 & 100 & 100 & 100 & 100 & 100,0 \\
\hline
\end{tabular}

Iturria: Euskobarometroa (2009).

2009ko datuei begiratuz, EAJren boto-emaileen artean gehiago dira independentzia nahi txikiak $(\% 38,2)$ edota batere nahirik ez dutela azaltzen dutenak $(\% 10,8)$, independentzia nahi handiak azaltzen dituztenak baino (\%37,5). EAren boto-emaileen \%56,5ak independentzia nahi handiak azaltzen ditu, \%30,4ak aldiz, independentzia nahi txikiak $(\% 21,7)$ edo batere nahirik ez duela azaltzen du $(\% 8,7)$. Aralarreko boto-emaileek ere jarrera beretsua erakusten dute, \%63,4ak independentzia nahi handiak azaltzen ditu, \%25,6ak aldiz, independentzia nahi txikiak (\%19,5) edo batere nahirik ez duela azaltzen du (\%6,1). 2005eko datuekin alderatuz, Aralarreko boto-emaileen artean independentzia nahi handiak txikitzen direla ikus dezakegu.

Grafikoa 4.5. 2009ko hauteskunde autonomikoetan alderdi abertzaleei bozka eman zietenen independendentzia nahi handiak (2009)

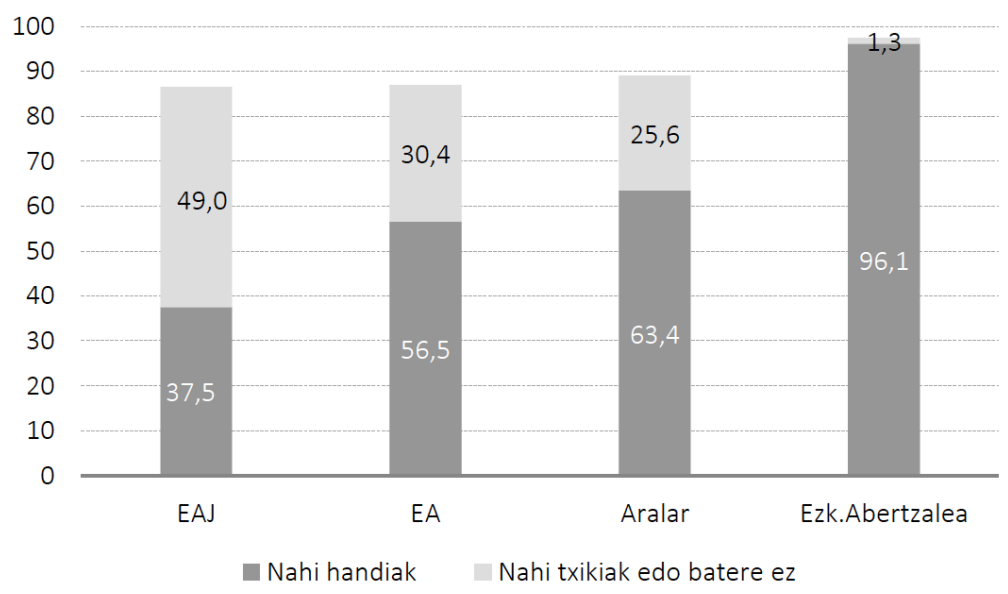

Iturria: Euskobarometroa (2009).

2005etik 2009ra independentzia nahi handiak azaltzen dituzten herritarren kopurua zertxobait txikitzen dela azaldu dugu, baina jaitsiera honen isla ez dugu alderdi abertzale guztietan ikusten. Ezker Abertzaleari erreparatzen badiogu, 2009an bozka balioabea egin zuen $\% 96,1$ ak independentzia nahi handiak azaltzen ditu. Aurretik ere aipatu dugun moduan, bozka abertzalea eta sentimendu independentistaren arteko jauzia hortaz, EAJri bozka ematen diotela adierazten dutenen posizioak eragiten du batik bat. 


\subsection{2ko hauteskunde autonomikoak}

2012ko hauteskunde autonomikoetan ere bada aldaketarik hauteskundeetara aurkezten diren aukera politikoei dagokionean. Izan ere, Ezker Abertzale historikoa, EA, Aralar eta Alternatibarekin batera EH Bildu koalizioan aurkeztuko da. 2012an gainera, alderdi abertzaleek jasotako bozka kopuruak gora egiten du; 662.689 bozka lortu zituzten. Boto baliodunaren \%58,8a eta erroldaren \%37,3a. 2013ko inkestan herritarren \%34,7ak azaltzen ditu independentzia nahi handiak. Aztergai ditugun aurreko urteetan bezala, alderdi abertzaleei bozka ematen dieten herritarrak independentistak baino gehiago dira.

Taula 4.11. Alderdi abertzaleek jasotako bozka kopurua (boto baliodunarekiko eta erroldarekiko \%) (2012)

\begin{tabular}{llll} 
& Bozka & Boto balioduna (\%) & Errolda (\%) \\
EAJ & 384.766 & 34,2 & 21,7 \\
\hline EH Bildu & 277.923 & 24,7 & 15,7 \\
\hline Bozka abertzalea & 662.689 & 58,8 & 37,3 \\
\hline Guztira & 1.135 .568 & 1.126 .400 & 1.775 .351 \\
\hline
\end{tabular}

Iturria: Eusko Jaurlaritza. Hauteskundeeetako Emaitzen Artxiboa.

Alderdi abertzaleetako boto-emaileei erreparatuz, EAJri bozka eman ziotela azaltzen duten herritarrak 2009ko ildo beretsua azaltzen dute 2013an; independentzia nahi txikiak $(\% 36,7)$ edota batere nahirik ez dutela azaltzen dutenak $(\% 12,8)$, independentzia nahi handiak azaltzen dituztenak baino gehiago dira $(\% 38,1)$. EH Bilduren boto-emaileek erakutsitako independentzia nahi handiak, Ezker Abertzale historikoaren boto-emaileenak baino zertxobait txikiagoak dira. Ziurrenik eragina izango du koalizioako kide diren EA, Aralar eta Alternatibako boto-emaileek independentzia nahiekiko izandako jarrera lausagoak. Hala eta guztiz, EH Bilduren boto-emaileen gehiengo zabalak independentzia nahi handiak azaltzen ditu. Alderaketa bat egitearren, 2013an EH Bilduren boto-emaileek erakutsitako independentzia nahia 2001ean EH koalizioaren boto-emaileek erakutsitakoaren parekoa da.

Taula 4.12. Independentzia nahiak 2012ko hauteskunde autonomikoetako bozka oroitzapenaren arabera (2013)

\begin{tabular}{lllllll} 
& EAJ & EH Bildu & IU/EB & PSE-EE & PP & Guztira \\
Nahi handiak & 38,1 & 79,4 & 32,4 & 3,9 & 0,0 & 34,7 \\
\hline Nahi txikiak & 36,7 & 7,8 & 37,8 & 19,4 & 25,8 & 22,8 \\
\hline Batere ez & 12,8 & 5,5 & 10,8 & 67,4 & 61,3 & 28,4 \\
\hline Axolagabe & 9,0 & 6,0 & 16,2 & 7,8 & 9,7 & 10,8 \\
\hline Ed/Ee & 3,5 & 1,4 & 2,7 & 1,6 & 3,2 & 3,3 \\
\hline Guztira & 100 & 100 & 100 & 100 & 100 & 100 \\
\hline
\end{tabular}

Iturria: Euskobarometroa (2013). 
Grafikoa 4.6. 2012ko hauteskunde autonomikoetan alderdi abertzaleei bozka eman zietenen independendentzia nahi handiak (2013)

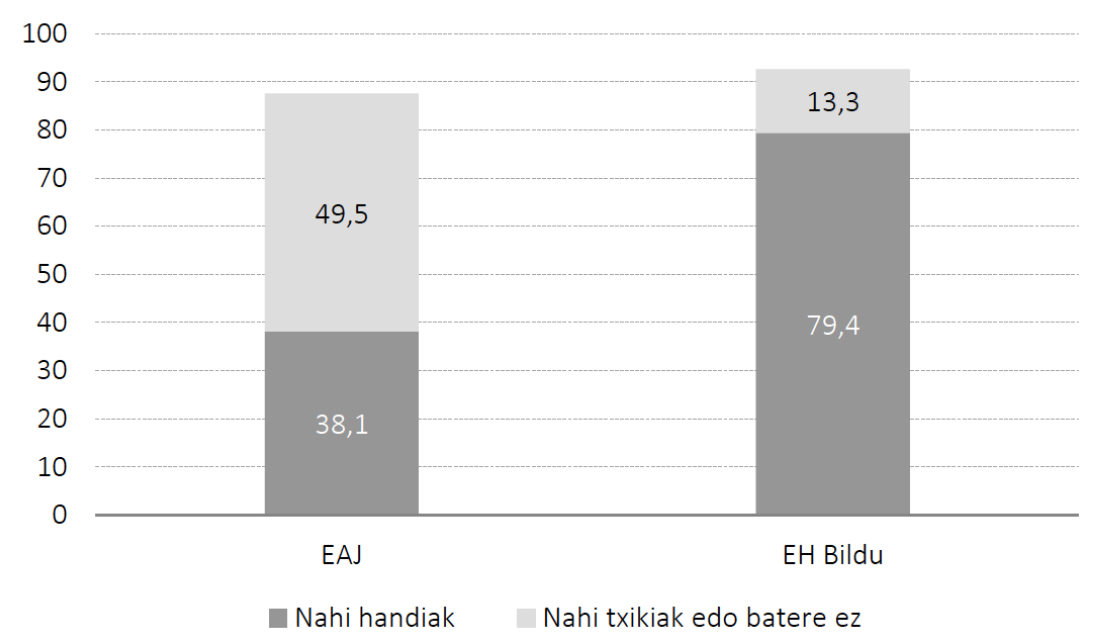

Iturria: Euskobarometroa (2013).

\section{ONDORIOAK}

1995-2013 tarteko datuei helduaz, hauteskunde portaera, eta zehazkiago, alderdi abertzaleek jasotako babesa, independentismoaren adierazle egokia ez dela agerian geratzen da. Hauteskunde portaeraren nondik norakoak hizpide izan ditugunean azaldu bezala, nortasun nazionalak eta nazionalismoak eragin handia dute hauteskunde portaeran, baina era berean, ez dira determinanteak. Ildo honi jarraiki, nortasun nazionala, ingurumaria konkretu batean aktibatua izan daiteke, baina horrek ez du zertan eragin zuzena izan behar banaketa edo independentziaren aldeko jarreretan. Hau da, nazio identitatearen indartzea ez da zertan islatu behar, edo ez maila berean, herritarren estatu egituraren edo ereduaren inguruko hautuan. 2001eko hauteskunde emaitzak bi dimentsioen ezberdintasunaren adierazle egokia dira; hauteskunde horietan, besteak beste, nortasun mobilizazioa medio, EAJk bozka kopuru handia irabazi zuen, baina, termino absolutuetan, bozka abertzaleak izandako hazkunde honek, ez zuen independentzia nahietan eraginik izan. Hau da, bozka abertzalearen gorakada ezin interpretatu ahal dugu independentziaren aldeko babesaren handitze bat bezala.

Modu orokorrean, alderdi abertzaleen bozka sentimendu independentistaren adierazle egokia ez dela adierazi dugu (ikus 5.1. Grafikoa). Alderdi abertzaleek 1994-2012 tartean jasotako bozka nahiko egonkor mantendu dela ikusi ahal izan dugu bozka hori modu bateratuan ulerturik behintzat. Hau da, alderdi abertzale ezberdinek jasotako bozkaren baitan aldaketarik egon da urte hauetan, eta indar korrelazio ezberdinak ikusi ditugu. Halere, bloke moduan ulerturik, ehunekoa nahiko egonkor mantentzen da aztergai izan dugun urte tarteetan. Era berean, herritarrek erakutsitako independentzia nahiek izan dute aldaketarik, eta, ondorioz, independentziaren inguruko jarrera aztertzeko herritarren hauteskunde portaeratik haratago joan behar gara. 
Grafikoa 5.1. Bozka abertzalea eta independentzia nahi handiak EAEn (1994-2013)

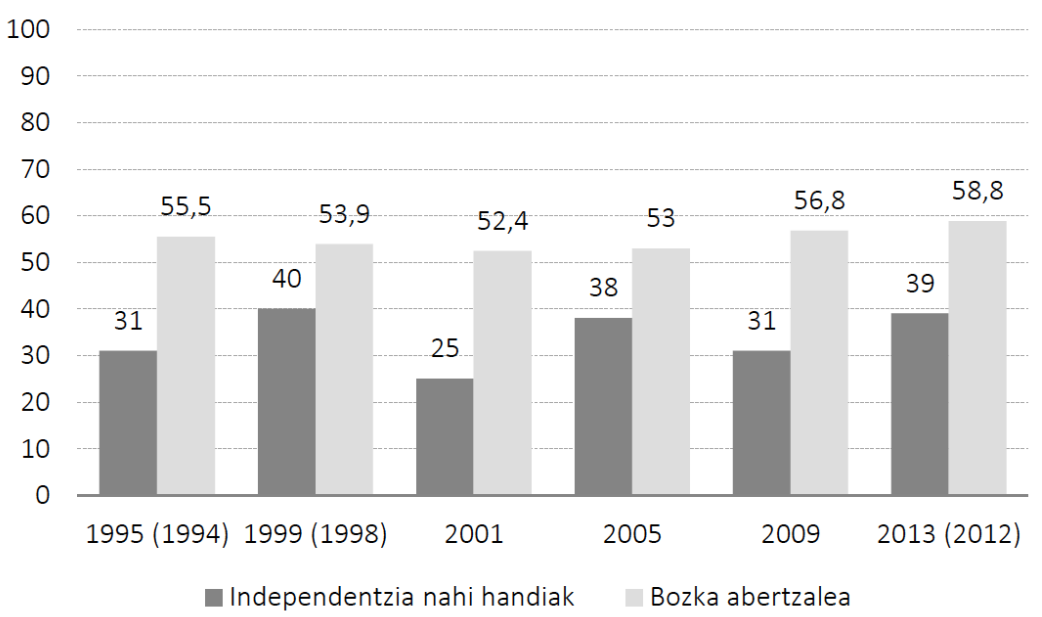

Iturria: Eusko Jaurlaritza. Hauteskundeeetako Emaitzen Artxiboa eta Euskobarometro Serieak.

Dena den, bozka abertzalea eta independentzia nahien artean ikusi izan ahal dugun jauzi hau ez da abertzaletasunaren bi familietan era berean islatzen. 1995-2013 bitarteko datuei erreparatuz, abertzaletasunaren baitako bi alderdi edo mugimendu nagusien boto-emaileen independentzia nahien bilakaera ezberdina ikus dezakegu. Boto-emaileen jarrera ezberdintasuna agerikoa da.

EAJren edo nazionalismo historikoaren jarraitzaileei dagokienean, banaketaren inguruko posizio ezberdinak ikus ditzakegu. 1995 eta 2005 urteetan, independentzia nahi handiak dituzten boto-emaileak, nahi txikiak edo batere ez dutela azaltzen dutenak baino gehiago dira. 1999an ere, baina aldeko eta kontrako jarreren gerturatze bat ikusi ahal dugu eta 2001ean gehiago dira independentzia nahi txikiak edo batere nahirik ez dutela azaltzen duten EAJ/EA koalizioko boto-emaileak.

Ezin dugu ahantzi 2001a dela, hizpide dugun urteetan, herritarrek independentzia nahi handiak era lausoenean azaltzen dituzten urtea. 2001ean gainera, koalizioak izugarrizko boto uholdea jaso zuen, PP-PSEren balizko gobernu baten mehatxupean. Ondorioz, koalizio abertzale honen gorakada eman zen, baina datuak erakutsi diguten bezala, igoera hau ezin dugu nahasi independentzia nahi handien igoerarekin. Gauza bat da koalizioari bozka ematea PP/PSE tandemaren beldur, eta, bestea, banaketaren aldeko jarrera izatea. 2009 eta 2013an EAJ bakarrik aurkezten da eta datuek argi erakusten dute boto-emaileen artean gehiago direla independentzia nahi txikiak edo batere ez dutenak, independentzia nahi handiak dituztenak baino. EAJren kasuan hortaz, bozka ez litzateke sentimendu independentistaren adierazle egokiena; independentzia nahirik ez duen hautesleen ehuneko esanguratsu batek ere bozka ematen dio EAJri. 
Grafikoa 5.2. Independentzia nahiak EAJren boto-emaileen artean (1995-2013)

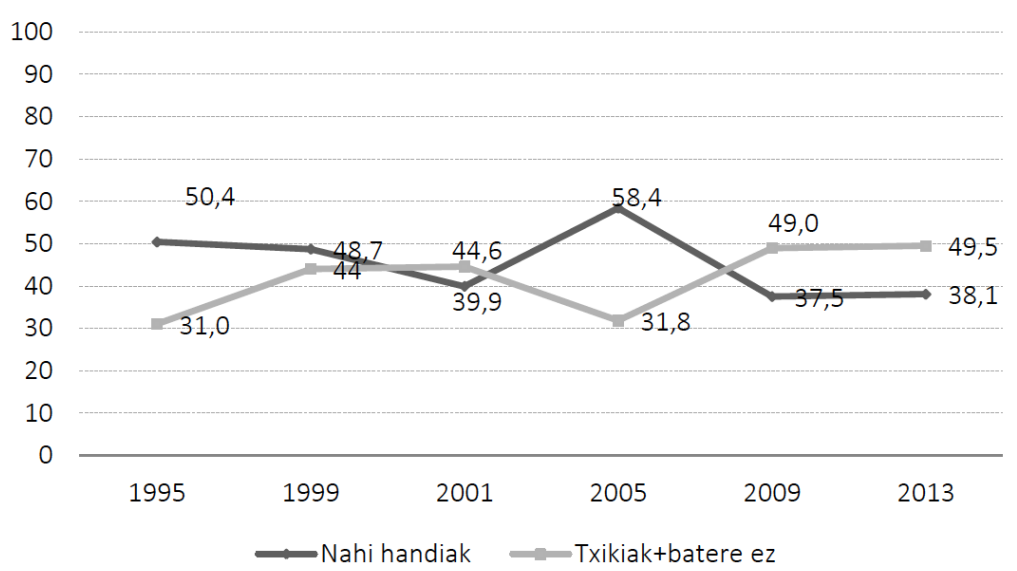

Iturria: Euskobarometro Serieak.

Ezker Abertzaleari dagokionean, 1995-2013 tartean, eta ilegalizazioak medio, alderdi edo koalizio ezberdinen bidez aurkeztu da hauteskunde autonomikoetara. Urte hauetan independentzia nahiek izandako gorabeherak ez dute eragin gehiegirik izan Ezker Abertzalearen boto-emaileen artean. Urtez urte, eta nazionalismo historikoaren jarraitzaileekin alderatuz, independentziaren aldeko nahi argiak erakusten dituzte. 2001 eta 2013 urteei erreparatuz, Ezker Abertzalearen boto-emaileen artean independentziaren aldeko nahiak zertxobait txikitzen direla ikus dezakegu. 2012an EH Bildurekin aurkeztean jarraitzaileen independentzia nahi handiak zertxobait txikitzen dira. Halere, Ezker Abertzalearen betiko boto-emaileen independentzia nahi handiak 2013an txikitu direla baino, koalizio ezberdinetako kide berrien jarraitzaileen independentziaren posizio ezberdinaz aritu beharko ginateke.

Grafikoa 5.3. Independentzia nahiak Ezker Abertzaleko boto-emaileen artean (1995-2013)

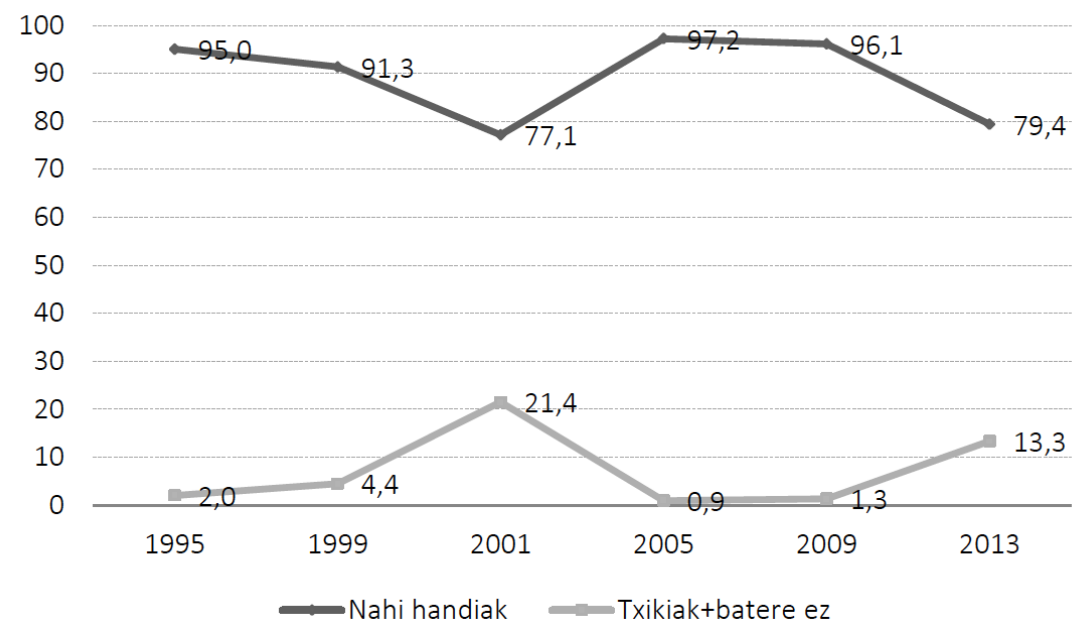

Iturria: Euskobarometro Serieak.

Alderdi abertzaleen bozka kopurua eta independentzia nahien arteko desakordioaz aritu bagara ere, alderdien bozka, sentimendu separatistaren adierazle egokia dela ere esateko moduan gaude alderdien diskurtso ezberdinduak baditugu oinarrian. EAJk historikoki independentziaren inguruan izandako diskurtso eta ibilbide politiko anbiguoa, bere boto-emaileen independentzia nahiekin bat datorrela esan genezake. Berdin Ezker Abertzalearekin, historikoki independentziaren aldeko hautua egin du, eta bere boto- 
emaileen independentzia nahiak alderdiak auzi honetan duen diskurtso eta praktikarekin bat datozela uste dugu. EAEko herritarren hauteskunde portaeraren gako nagusiak hizpide izan ditugunean azaldu bezala, enpirikoki ezin dugu jakin ardatz ideologikoa oinarri egiten duten Ezker Abertzalea eta EAJren inguruko hautua edota beste irizpide batzuk gailentzen diren. Kultura politikoa, ibilbide historikoa eta independentismo maila ere aintzat hartu beharreko faktoreak dira gure ustean eta agerikoa da independentziaren inguruko posizio ezberdinduak azaltzen dituztela EAEko abertzaletasunaren baitako bi familia politikoen boto-emaileek.

Laburbilduz, independentzia nahien gorabehera batzuk ikus ditzakegu azterturiko seriean, bozka abertzalea aldiz, nahiko egonkor mantendu da. Bozkaren baitan eman ahal diren aldaketak beraz, ez dute derrigorrean independentismoan eraginik izan behar. Bozka abertzalea eta indepentismoaren arteko lotura hertsia Ezker Abertzalearen baitan bakarrik ikusi dezakegu. 2001ean EAJ alderdiak jasotako bozka uholdea eta urte horretan bertan bere boto-emaileek azaldutako independentzia nahi handi lausoek ere agerian uzten dute alderdi abertzaleen bozka eta independentismoaren dimentsioak ezberdintzearen beharra. Une konkretuetan, nortasun mobilizazioa indartzeak, eta ondorioz, gutarren gobernuaren aldeko hautua egitea ordea, ezin dugu parekatu banaketaren aldeko jarrera handiago batekin.

Hauteskunde portaeraren nondik norakoak aztertzean, EAEn jatorriak eta nortasun nazionalak duen garrantziaz aritu gara. Nortasun nazionala gainera, nazionalismoaren balio politikoan bilaka daiteke, modu honetara, bozka baldintzatzuz. Hauteskunde testuinguruari dagokionean berriz, uneko alderdi abertzale/ez abertzaleen arteko indar korrelazioa izan dugu hizpide. Aurkezturiko datuek ordea, agerian uzten dute hauteskunde emaitzetatik independentziaren inguruko posizio argirik ezin dela iradoki. Honela, hauteskunde portaera aztertzeko kontuan izan ditugun faktoreak ez dira independentziaren babesa ezaugarritzeko egokiak Abertzaletasuna eta alderdi abertzaleek jasotako bozkaren artean paralelismo bat egin ezin dezakegun moduan, alderdi abertzaleen bozkaren gorakada edo beherakada batetik ezin ondorioztatu ahal dugu independentzia nahien aldaketa bat. Hortaz, indar abertzale eta eta ez abertzaleen arteko indar korrelazioa ez da, bere hortan, independentziaren adierazle egokia, dimentsio ezberdinen arteko elkarrekikotasun konplexuago baten aurrean gaude. 


\section{BIBLIOGRAFIA}

Almond, G., and Verba, S. (1992). La cultura política. En Diez textos básicos de Ciencia Política (pp. 171-201). Barcelona: Ariel.

Anduiza, E., y Bosch, A. (2012). Comportamiento político y electoral. Barcelona: Ariel.

Campbell, A., Converse, P., Miller, W., and Stokes, D. (1960). The American Voter. Nueva York: Iohn Wiley.

Carmines, E., and Huckfeldt, R. (2001). Comportamiento político: una vision general. En Goodin, R., and Klingemann, H.D. (eds.), Nuevo manual de Ciencia Política (pp. 329373). Madrid: Istmo.

Clark, T., and Lipset, S. (2001). The breakdown of class politics: a debate on post-industrial stratification. Woodraw Wilson Center Press.

Conversi, D. (1997). The Basques, the Catalans and Spain. Alternative Routes to Nationalist Mobilisation. Londres: Hurts and Co.

Downs, A.(1957). An Economic Theory of Democracy. Nueva York: Harper and Row.

Hale, H. (2008). The foundations of ethnic politics: separatism of states and nations in Eurasia and the world. Cambridge: Cambridge University Press.

Harrop, M., and Miller, W. (1987). Elections and voters: a comparative introduction. London: Mac Millan

Johns, R. et al. (2009). Valence politics in Scotland: Towards an explanation of the 2007 election. Political Studies, vol. 57, n¹, pp. 207-233.

Lazarsfeld, P., Berelson, B., and Gaudet, H. (1944). The People Choice: How the voters makes up his mind in a presidential campaign. Nueva York: Columbia University Press.

Lipset, S., and Rokkan, S. (1992). Estructuras de división, sistemas de partidos y alineamientos electorales. En Batlle, A. (ed.), Diez Textos Básicos de la Ciencia Política (pp.231-273). Barcelona: Ariel.

Máiz, R. (2003). Politics and the Nation: Nationalist Mobilisation of Ethnic Differences. Nations and Nationalism, vol.9, n², pp. 195-212.

Mayer, N. (2006). Qui vote pur qui et porquoi? Les modeles explicatifs du choix electoral. Pouvoirs, vol. 120, nº1, pp. 17-28.

McCrone, D., and Lindsay P. (2002). The conundrum of Scottish Independence. Scottish Affairs, vol.40, pp. 54-75. 
Montero, J.R. and Font, J. (1991). El voto dual: lealtad y transferencia de votos en las elecciones autonómicas. Estudis Electorals, nº10, pp. 183-221.

Montero, J.R., and Font, J. (1989). El voto dual en Cataluña: dimensiones, sujetos y factores. Barcelona: Mímeo.

Norris, P. (2006). Electoral engineering: voting rules and political behaviour. Cambridge: Cambridge University Press.

Pallarés, F. (2002). Las elecciones autonómicas de mayo 2001 en el País Vasco. Informe de las Comunidades Autónomas 2001.

Pallarés, F., y Font, J.(1994). Las elecciones autonómicas en Cataluña 1980-1992. En Del Castillo, P. (ed.), Comportamiento político y electoral (pp. 178-210). Madrid: CIS.

Paterson, L. (2003). Scottish education in the twentieth century. Edinburgh: Edinburgh University Press.

Pattie, C., Denver, D., Mitchell, J., and Bochel, H. (1999). Partisanship, national identity and constitutional preferences: an exploration of voting in the Scottish devolution referendum of 1997. Electoral Studies, vol. 18, pp. 305-322.

Pérez-Nievas, S., y Bonet, E. (2005). El voto a partidos nacionalistas en Europa. El impacto de factores individuales sobre el voto a partidos nacionalistas periféricos en Bélgica, España, y Reino Unido. Departamento de Ciencia Política y Relaciones Internacionales, Serie Estudios/Working Papers, nº 56.

Rose, R. (2000). International encyclopedia of elections. London: Macmillan.

Serrano, I. (2013). Just a matter of identity? Support for Independence in Catalonia. Regional and Federal Studies, vol. 23, nº 5, pp. 523-545.

Sorens, J. (2005). The cross-sectional determinants of secessionism in advanced democracies. Comparative political studies, vol.38, n³, pp. 304-326.

Sulmont Haak, D. (2010). Los enfoques teóricos sobre el comportamiento electoral. Perú: Pontificia Universidad Católica del Perú.

Thomaseen, J. (2005). The European voter: a comparative study of modern democracies. Oxford: Oxford University Press.

Türsan, H. (1998). Introduction: Ethnoregionalist parties as ethnic entrepreneurs. Regionalist Parties in Western Europe, pp.1-16. 